Teologia i Moralność, Volumen 15(2020), numer 2(28)

doi: 10.14746/tim.2020.28.2.11

ORCID: 0000-0003-4212-2711

BORYS JACEK SOIŃSKI

Adam Mickiewicz University in Poznań

Faculty of Theology

\title{
Selected indicators of religiosity of postgraduate students of Theology in Poznan
}

In 2016 the Faculty of Theology at AMU opened two new postgraduate programs in theology ${ }^{1}$ which do not conclude in a $\mathrm{PhD}$ diploma but rather aim to prepare the graduates to teach religion as a school subject and to conduct religious instruction in kindergartens. The first of these programs is the Postrgraduate Study in Theology and Catechesis which is open to holders of B.A or higher degrees who are certified to teach any subject in state schools (Marciniak 2016a). The other is the Postgraduate Study in Preschool Catechesis aimed at graduates of Preschool and Early School Education programs. (Marciniak 2016b). The students in both these programs, while obtaining certification to teach religious instruction, become theologians. This makes it particularly important for them to have spiritual competences related to spiritual development and developing faith such as the capacity to guide their own personal development, high personal ethics and ethical sensitivity towards social and religious issues and, above all, the capacity for supporting their students spiritually (Marciniak 2016a; Marciniak 2016b).

This gives rise to the question: are the current students in these programs in fact persons who have the spiritual competences related to their own spiritual development and the development of faith and who in future will be able

${ }^{1}$ These programs were created on the basis of The Resolution of The Episcopal Conference of Poland from the 7th of June 2016 regarding the minimum requirements in the training of school catechists [Uchwała Konferencji Episkopatu Polski z dnia 7 czerwca 2016 roku w sprawie minimalnych wymogów w kształceniu nauczycieli religii] (KEP 2016), which is based in the existing state legislation. The competences of school catechists are regulated by:agreement between The Episcopal Conference of Poland and the Ministry of National Education from the $31^{\text {st }}$ of May 2016 regarding the required qualifications of school catechists [Porozumienie pomiędzy Konferencją Episkopatu Polski oraz Ministrem Edukacji Narodowej z dnia 31 maja 2016 r. w sprawie kwalifikacji wymaganych od nauczycieli religii] (2016). 
to offer adept spiritual support to their students? Are they religious and can their religiosity be regarded as mature?

\section{A theologian's experience of faith}

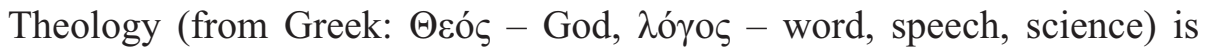
a particular academic discipline, because it answers questions related to the issues of God and humankind in the light of reason and faith (Szymik 2013, 657). To define it in the broadest sense, we can say that it is discipline that relies on scientific study of the Revelation, tradition and teachings of the holy Church (Magisterium Ecclesiae). At the same time it is a type of intellectual activity that exposes and develops the theologian's inner, spiritual experience of sacrum. As noted by Janusz Królikowski, this inner experience is in fact faith itself (Królikowski 2017, 25). Furthermore, living faith expresses itself in good deeds (cf. Jacob 2:17), and most of all: in actions based in the love of God and man (cf. Gal. 5,6). This has been emphasized by such witnesses to theology as St. Augustine, St. Thomas Aquinas or St. Bonaventure. Consequently, living faith that expresses itself trough love comprises of prayer and other religious practices and ecclesiastic engagement, which satisfy authentic yearning for God (Królikowski 2016, 232, 298). Because theology, as scientia fidei, is based on the mutual bond between science and faith, it is impossible to be a theologian without inner faith experience, without inner identification with God and without expressing the union with Him trough individual and community prayer. Knowledge acquired during the study of theology can comprise exegesis, the history of Church, the development of doctrines and philosophical reflection, but these are all only auxiliary fields of theology, given that the true aim of this discipline is the sanctifying communion with God - a union that eventually leads to salvation. The task of a theologian lies not as much in explaining the mysteries of faith, but rather in arousing others' experience of God's mystery. However, in order to give God one must first receive God personally to be able to pass onto others the authentic sense of the mystery (Królikowski 2017, 28-29). Like Hans Urs von Balthasar, one must highlight the need for „kneeling theology”, meaning theology in the closeness of God, which is also the point of arrival of the ,sitting theology" - the result of individual study by the scholars' desk or instruction undertaken under the guidance of mentors and masters in the lecture hall. The religious attitude of a theologian should also have the characteristics of a synderetic, habitual engagement, which lays the foundation for theological study and deep, intellectual research (Królikowski 2017, 29-29). It should be remembered that a theologian should not just experience God's mystery in particular moments, but 
rather continuously, given that he or she is included in this mystery together with his or hers life situation, and it shapes his or hers entire thinking and lifestyle (Królikowski 2018,30).

A theologian's experience of faith has been described by Grzegorz Strzelczyk. The experience of faith is at first a mediator of the reception of Revelation, which always stands at the centre of human experience of faith. The reception, interiorisation and objectivisation of God's Revelation enables theological reflexion. Interiorisation comprises the consolidation of Revelation with the whole of one's personal experiences, whole objectivisation means the confrontation of one's personal experiences with the experience and interpretative tradition of the community. Such an experience later creates testimony for others, who are also the recipients of theological discourse. The passing from Divine Revelation to theology can be expressed in the following sequence: experientia - testimonium (communio) - theologia. Thus the experience of faith precedes theology in two ways. Firstly it precedes it chronologically, as the conditio sine qua non of Revelation, and secondly - in the sense of forming the necessary foundation and the source of theology (LG 8; Strzelczyk 2007, 42-43). A theologian's personal experience of faith is in fact framing oneself in relation to the Ressurected Jesus Christ who is still present in the holy Church, the sacraments, prayer and other religious practices. This experience is subject to primary reflection and then in turn influences the way in which the theologian sees him- or herself and his or hers general outlook on reality. The theologian's experience of faith is, thus, an integral element of the theological method and ,theology practised without it is by necessity methodologically wrong" (Strzelczyk 2006, 46). In consequence, the practice of theology without methodologically structured, scientific reflection upon the Revelation and the theological tradition can no longer be considered theology but rather a kind of religious studies or history of religion. Separating theology from experience may cause the former to no longer be credible or convincing.

\section{Psychological understanding of religiosity}

The notion or category of „experience”, which has become common and indispensable in contemporary theological reflection, has, however, provoked much controversy due to its lack of precision which often results in ambiguous approaches. At times, this notion is used to highlight the originality and relevance of a given framework, in other cases - to emphasize a particularly empirical moment, and frequently - to express a reality that is hard to capture and somewhat mysterious (Kowalik 2003, 36-38). Current and future methodological inquiries are most likely to prolong this discussion amongst theolo- 
gians, but for the purpose of this psycho-pastoral analysis, the understanding of the experience of faith shall be narrowed down to its empirical dimension. Faith, is however, an occurrence characterized by particular mysteriousness which makes it difficult to capture in empirical definitions or objective descriptions (Moskałyk 2012, 42). This is why psychology usually employs the notion of religiosity in this context ${ }^{2}$. The diversity of methodological approaches results in many different, and at times contradictory, interpretations of the phenomenon of religiosity (Chlewińki 1982b, 11; Nowak 1985, Król 2002, 88). Zdzisław Golan defines religiosity as ,a subjective positioning of a human being in relation to God and transcendence, expressed in the realm of notions, beliefs, feelings and actions of an individual" (Golan 2006, 71). This means that religiosity comprises of inner psychological processes of an individual related to his or hers experience of a particular relationship with God, who is regarded by the subject as a reality existing outside of the visible realm. Czesław Walesa, on the other hand, states that „religiosity is a personal, subjective, individual and positive relation between an individual and religion" and that ,religiosity is the sum of everything that an individual experiences and all of what happens, changes or functions within the individual in direct interrelation with the relationship with God in which this particular person has places him or herself' (Walesa 1982, 144). Romuald Jaworski also understands religiosity as the subjective side of a religious phenomenon which comprises religious beliefs, experiences and pursuits as well as their external manifestations, but whose core is the personal relationship with God (Jaworski 1989, 10-12).

A vast array of research has been conducted on religiosity of university students (eg. Głaz 2004). Religiosity of postgraduate students has also been studied (Hay 1979). In the context of this article's topic, one should pose the following question: is it possible that there is a interrelation between the kind of an academic program one attends and one's religiosity? So far, research has been conducted, for example on the relationship between the course of study and views on the relations between religion and science (eg. Scheitle 2011). There are also studies that indicate that there is some interrelation between the academic discipline and religiosity (eg. Stark, Finke 2000; Gross, Simmons 2009; Sheitle, Ecklund 2018). Research conducted by Polish sociologists identified field of study as a more significant variable for students' religiosity than gender: being religious was less common among students of humanities $(54 \%)$ than among students of technical faculties, while natural sciences had

${ }^{2}$ D.M. Wulff prefers the term „religious faith” to „religiosity” (Wulff 1999, 513). However, the use of the term ,faith" in psychology often seems problematic from the point of view of theology and does not bring the intended clarity to the explanation of this notion. 
the highest percentage of religious students. Other studies have shown that religious orthodoxy was the most common among students reading Polish, followed by those included in mathematics and physics programs, while it was the least common among students of social sciences (Miś, Warmiński 2000, 104). Anna Królikowska's research has proven that religiosity and understanding of religious notions is chiefly influenced by the differences in mentality between students of humanities, engineering and medicine (Królikowska 2009).

Stanisław Głaz's research, in turn, has shown that religious involvement, experiences and practices are most correlated with studying theology. Theologians took part in sacramental life more often and showed higher levels of individual prayer and religiosity than students of forestry (Głaz 2003, 130). Similar dependencies have been proven in research on students' religious experiences in the wake of John Paul II's death, when students of theology reported stronger sensations of closeness to God than student's of medicine or education sciences (Soiński 2006, 65-66). In case of students of philosophy the results were more ambiguous. They had higher scores for some indicators describing their religiosity (such as religious involvement or experiences), but the control group of their peers pursuing vocational education showed more involvement in sacramental life (Głaz 2004, 97).

\section{Research methods and characteristics of the research subjects}

This article aims to answer the following research question: Are there significant differences in:

- the declared faith and image of God;

- involvement in sacramental and religious life;

- involvement in the life of Church communities;

- religious identity;

- and personal religiosity

between the students in the postgraduate programs in theology and other adult Catholics with higher education.

The following hypothesis has been formulated to answer the question:

Postgraduate students of theology have a more filial image of God, show a higher level of religious practices and ecclesiastic engagement, as well as a more mature religiosity than the control group of adult Catholics with higher education. 
In order to verify this hypothesis, survey method has been employed, using the following tools: questionnaire for researching the dimensions of religiosity developed by the author, W. Prężyna's/W. Chaim's Scale of Religious Practices (Chaim 1991, 120, 195), A. Wieradzka-Pilarczyk's Scale of Religious Identity (Wieradzka-Pilarczyk 2015, 147-154) and R. Jaworski's Scale of Personal Religiosity (Jaworski 1989, 10-12).

The research was conducted between 2017 and 2019 among the students of Postgraduate Study in Theology and Catechesis and Postgraduate Study in Preschool Catechesis at the AMU Faculty of Theology in Poznan. The respondents were asked to fill out the questionnaires during classes. The choice whether to participate was theirs, yet nobody declined. Out of 71 answer sets $\mathrm{N}=62$ were verified as complete and taken into account in further analyses. The experimental group included 54 laypersons and 8 consecrated persons or members of the clergy. Due to the age group represented by the participants, parents whose children preparing for the First Communion and who had higher education $(\mathrm{N}=145)^{3}$. All of the participants were Roman Catholics. In both groups women were the majority $(81.2 \%)$. Among the postgraduate students $88.7 \%$ were women. The percentage in the reference group was somewhat lower $-77.9 \%$. The difference, however, is not statistically significant.

Table 1. Descriptive statistics of the age variable among the research participants $(\mathrm{N}=207)$

\begin{tabular}{|c|c|c|c|c|c|c|c|c|}
\hline Age & $\mathbf{N}$ & Min & Max & $\mathbf{M}$ & SD & Skewness & Kurtosis & $\begin{array}{c}\text { Mann-Whitney } \\
\text { test } \\
\text { confidence level }\end{array}$ \\
\hline $\begin{array}{l}\text { Postgraduate } \\
\text { students }\end{array}$ & 62 & 24 & 56 & 39.32 & 8.24 & 0.06 & -0.93 & \multirow{2}{*}{ Insignificant } \\
\hline $\begin{array}{l}\text { Reference } \\
\text { group }\end{array}$ & 145 & 28 & 57 & 38.77 & 4.85 & 0.90 & 1.78 & \\
\hline
\end{tabular}

The age differences between the two groups are not statistically significant. As table 1 shows, the average age $(M=39.8$ and $M=38.8)$ and the minimum and maximum ages are close in both groups. The main differences between the two groups lies in the fact that in the postgraduate students group the age distribution is symmetrical (the asymmetry is close to 0.1 ), while the reference

\footnotetext{
${ }^{3}$ Parents of children preparing for the First Communion were surveyed by Jan Cieślak, Elżbieta Rychlik and Karolina Staszak as part of a research program conducted in the years 2009-2018 at the pastoral psychology seminar. Due to slight variations between questionnaires used during different waves of the survey, the size of the reference groups differs between the items.
} 
group shows skewness to the right (0.9), which means that younger people were represented in higher numbers.

Table 2. Places of residence of research participants $(\mathrm{N}=207)$

\begin{tabular}{|c|c|c|c|c|c|}
\hline \multirow[t]{2}{*}{ Place of residence } & \multicolumn{2}{|c|}{$\begin{array}{l}\text { Postgraduate students } \\
\qquad(\mathrm{N}=62)\end{array}$} & \multicolumn{2}{|c|}{$\begin{array}{l}\text { Reference group } \\
\qquad(\mathrm{N}=145)\end{array}$} & \multirow{2}{*}{$\begin{array}{c}\text { Mann-Whitney } \\
\text { test } \\
\text { confidence level }\end{array}$} \\
\hline & $\mathbf{n}$ & $\%$ & $\mathbf{n}$ & $\%$ & \\
\hline Rural areas & 25 & 40.32 & 15 & 10.34 & \multirow{4}{*}{0.001} \\
\hline $\begin{array}{l}\text { Towns under } \\
10,000 \text { inhabitants }\end{array}$ & 9 & 14.52 & 8 & 5.52 & \\
\hline $\begin{array}{l}\text { Towns between } \\
10,000 \text { and } 200,000 \\
\text { inhabitants }\end{array}$ & 15 & 24.19 & 11 & 7.59 & \\
\hline $\begin{array}{l}\text { Cities over } 200,000 \\
\text { inhabitants }\end{array}$ & 14 & 22.58 & 111 & 76.55 & \\
\hline
\end{tabular}

The largest share of postgraduate students who took part in the research lives in rural areas (40.3\%), while the smallest share resides in small towns $(14.5 \%)$. Almost a quarter of the students $(24.2 \%)$ live in middle-sized towns while, $22.6 \%$ live in large cities.

Table 3. Marital status of the research participants $(\mathrm{N}=207)$

\begin{tabular}{|c|c|c|c|c|c|}
\hline \multirow[t]{2}{*}{ Marital status } & \multicolumn{2}{|c|}{$\begin{array}{l}\text { postgraduate students } \\
\qquad(\mathrm{N}=62)\end{array}$} & \multicolumn{2}{|c|}{$\begin{array}{l}\text { reference group } \\
\qquad(\mathrm{N}=145)\end{array}$} & \multirow{2}{*}{$\begin{array}{c}\text { Mann-Whitney } \\
\text { test } \\
\text { confidence level }\end{array}$} \\
\hline & n & $\%$ & n & $\%$ & \\
\hline Sacramentally married & 36 & 58.06 & 112 & 77.24 & \multirow{7}{*}{0.05} \\
\hline Single & 14 & 22.58 & 2 & 1.38 & \\
\hline $\begin{array}{l}\text { Consecrated } \\
\text { person/member } \\
\text { of the clergy }\end{array}$ & 8 & 12.90 & 0 & 0 & \\
\hline Divorced & 3 & 4.84 & 3 & 2.07 & \\
\hline Widowed & 1 & 1.61 & 2 & 1.38 & \\
\hline In informal cohabitation & 0 & 0 & 16 & 11.03 & \\
\hline civilly married & 0 & 0 & 9 & 6.21 & \\
\hline
\end{tabular}


In the examined group of postgraduate students the most (58.1\%) are sacramentally married, while $23.0 \%$ are single. Every eight person in this group is consecrated or a clergyman, and while $4.8 \%$ are divorced none of them have entered new relationships and they live alone. In this group there are no people in informal cohabitation or civil marriages. In the reference group, on the other hand, over three quarters $(77.2 \%)$ are sacramentally married $(77.2 \%), 11.2 \%$ are in informal cohabitation, $6.2 \%$ in civil marriages, and $2.1 \%$ are divorced. This means that there is a notable difference between the postgraduate students of theology and the reference group where it comes to marital status, given that the status of $95.2 \%$ of the students can be considered canonically regular, while in the other group every fifth person is a so called ,martially irregular situation".

\section{Profession of faith of the research participants}

The analysis of research outcomes shows that $40.3 \%$ of postgraduate students of theology declare to be of profound faith (Table 4). Meanwhile, in the reference group much fewer people declare to be deeply religious $(10.4 \%)$ - the percentage is close to that of Poles who declared profound faith in the Statistics Poland research conducted in $2015^{5}$. The difference in the declared level of faith between the two groups is statistically significant at the level of $\mathrm{p}<0.001$. There is, however only a small difference when it comes to the percentage of people who declare themselves as religious in both groups $(60.0 \%$ and $53.0 \%$ ). No one among the postgraduate students who took part in the research declares to be mostly religious, neutral towards faith and religion, mostly irreligious or irreligious, while in the reference group $30 \%$ declare to be mostly religious.

One must remember, however, that declarations of profound faith do not always correspond with deep religiosity. The research of Polish sociologists has shown that Catholics in Poland who declare themselves to be profoundly religious, often do so because of a very emotional, traditional attachment to the „faith of forefathers”. In case of such persons, declaration of profound faith sometimes means strong involvement in tradition as well as strong religious socialization in their families (Piwowarski, Mariański, Ryczan 1987, 116).

\footnotetext{
${ }^{4}$ However in the light of Amoris laetitia: ,it is can no longer simply be said that all those in any 'irregular' situation are living in a state of mortal sin and are deprived of sanctifying grace" (AL, $301)$.

${ }^{5}$ According to the Statistics Poland survey, $10.5 \%$ of Poles declare to be deeply religious, while the percentage for the 35-54 age group is 8.8-9.1\% (Statistics Poland, Statistical Office in Lódź 2017, 116).
} 
Table 4. Research participants attitudes towards faith and religion $(\mathrm{N}=177)$

\begin{tabular}{|l|c|c|c|c|c|}
\hline & \multicolumn{2}{|c|}{$\begin{array}{c}\text { Postgraduate students } \\
\text { (N=62) }\end{array}$} & \multicolumn{2}{c|}{$\begin{array}{c}\text { Reference group } \\
\text { (N=115) }\end{array}$} & $\begin{array}{c}\text { Mann-Whitney } \\
\text { test } \\
\text { confidence level }\end{array}$ \\
\cline { 2 - 5 } & $\mathbf{n}$ & $\mathbf{\%}$ & $\mathbf{n}$ & $\mathbf{\%}$ & \\
\hline Deeply religious & 25 & 40.32 & 12 & 10.43 & \\
\hline Religious & 37 & 59.68 & 61 & 53.04 & \\
\hline Mostly religious & 0 & 0 & 35 & 30.43 & \multirow{2}{*}{0,001} \\
\hline Neutral & 0 & 0 & 3 & 2.61 & \\
\hline Mostly irreligious & 0 & 0 & 2 & 1.74 & \\
\hline Irreligious & 0 & 0 & 0 & 0 & \\
\hline No data & 0 & 0 & 2 & 1.74 & \\
\hline
\end{tabular}

Graph 1. The beliefs of the research participants on whether their faith in God gives meaning to their lives $(\mathrm{N}=177)$

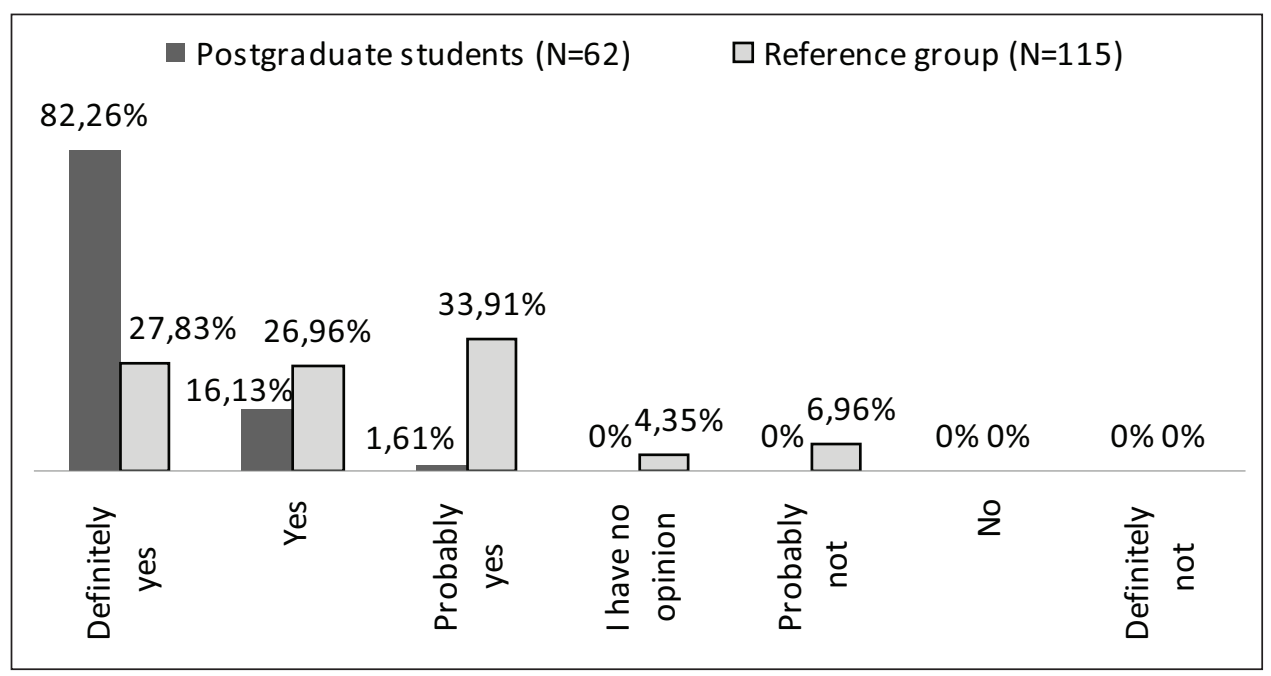

The results of Mann-Whitney test show that the difference is statistically significant at $\mathrm{p}<0.001$

An important element constituting religiosity is religious faith understood as a set of notions and statements related to God, humankind and the world. In the psychological perspective, faith provides answers to important existential questions and allows for fulfillment of one of individual's basic needs, namely the need for Transcendence. By explaining the meaning and purpose of life, it enables one to interpret life, suffering, death and other liminal situations as 
having worth for the particular person or for others (Chlewiński 1982, 70). As is shown in Graph one, the postgraduate students of theology are statistically more likely $(\mathrm{p}<0.001)$ than other adult Catholics to be of the mind that faith in God definitely gives meaning to their lives. ( $82.3 \%$ as compared to $27.8 \%$ ). In contrast to the postgraduate students, every third person in the reference group answered yes, but with little certainty. Moreover, $7.0 \%$ of adult Catholics in the reference group disagrees somewhat with the view that there's a connection between faith and the perception of life's meaning, and $4.4 \%$ have no opinion on this subject. These views were not represented among postgraduate students of theology.

In the theological dimension, God is the Father to Christians ${ }^{6}$. God was described as Father chiefly by Jesus in the Gospels (Mark: in 4 instances; Matthew: in 43 instances; Luke: in 15 instances; John: in 109 instances), who - while teaching the new prayer to his disciples - has also explicitly shown God's closeness by using the term Abba (cf. Mark 14:36), which is an equivalent of the diminutive „daddy" (Kwas 1982, 187). When presented with several descriptors of who God is for them, the respondents who chose the first answer - „beloved Dad" - showed that they are conscious of the most faithful reading of the Gospels and are personally, filially devoted in their relationship to God. As shown in Graph 2, the majority of postgraduate students of theology has chosen this option $(61.3 \%)$, while in the reference group one in five respondents $(19.1 \%)$ shares this view of God $(p<0,001)$.

The second descriptor of God, ,friend”, also signifies a personal bond between an individual and God, but in the light of the Bible this bond is based on the covenant (Poniży 2003) and not on generation as it was in the case of the above-mentioned Father-child relationship. For Christians, the term "friend" has christological connotations - it mostly refers to Jesus who had close Friends (cf. Luke 10:37-42; John 11:1-44, 12:1-11) and was referred to as a friend of sinners (cf. Luke 7:13). However, in its theological sense, this description calls back mainly to the words He shared with his disciples at the cenacle. A bond of friendship with Jesus stems from having been chosen by Him and is related to fulfilling His commands (cf. John 15:13-16; Luke 12:4). Almost three quarters of postgraduate students of theology chose to describe God as Friend, while only $39.1 \%$ of adult Catholics in the reference group selected this option. This indicates that future catechists have a closer relation with God. The descriptors of „Teacher” and „Judge” were selected less often,

${ }^{6}$ However, God is the Father not only to Christians, given that the Old Covenant already applied the image of father to God (Prov 3:12; 2 Sam 7:14; Deut 8: 5, 32: 6-19; Mal 1:6; 2: 1-3).However, for Hebrews the father-child relationship with God was mostly interpreted in its legal aspect of reprimanding and disciplining the Children, while the new testaments puts emphasis on grace and closeness (Łabuda 2011, 173, 176). 
but the numbers were comparable in both groups. The descriptor of God as Someone inaccessible was selected by almost one in ten respondents from the reference group and only by several people in the experimental group. The respondents were also free to add their own descriptions - those who decided to do so, listed the following: Love (x2), the Absolute, Lord, Creator, Mystery, Guide, Employer, good Boss.

Graph 2. The research participants' notion of God (N=177)

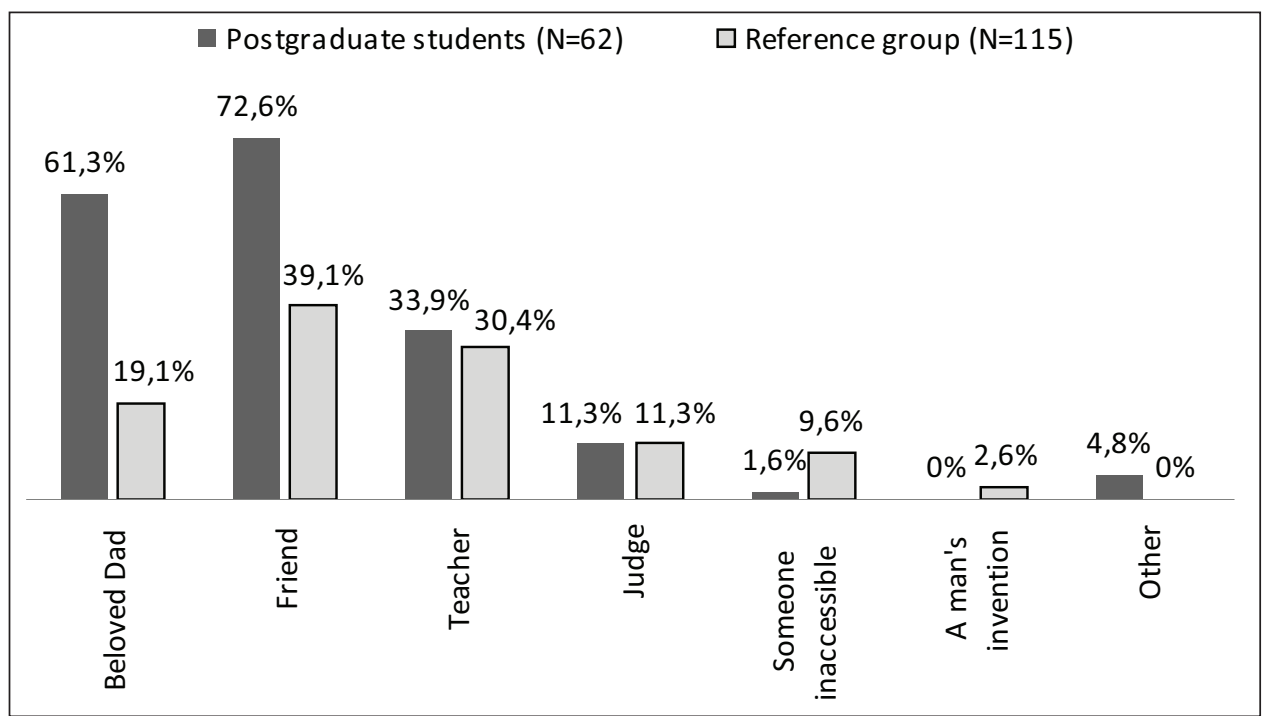

Some of the participants selected more than one option, which makes the total sum greater than $100 \%$. The Mann-Whitney test indicates statistic significance of the difference at the level of $\mathrm{p}<0.001$

The right notion (image) of God is, according to Zdzisław Chlewiński, one of the characteristics of religious maturity (Chlewiński 1991, 92-95). In the light of the conducted analyses, it is evident that the postgraduate students of theology show significantly greater religious maturity than the Catholics from the reference group $(\mathrm{p}<0.001)$.

The declarations concerning personal faith in God (Graph 3) allow to state that it is much more common for the postgraduate students of theology to have no doubts as to the existence of the God they believe in (79.0\% as compared to $51.3 \%$ ). In the reference group of other adult Catholics, on the other hand, there is a greater percentage of people who experience passing doubts as to Gods existence (37.4\% as compared to $21.0 \%$ ), and there are also persons who only believe in ,some kind of Higher Power" $(6.0 \%)$ or declare their faith to be labile (5.2\%). 
Graph 3. The respondents' answers to the question: „Which of the following statements do you agree with the most?" $(\mathrm{N}=177)$

\begin{tabular}{|c|c|}
\hline \multirow{3}{*}{$\begin{array}{c}\text { I believe in God and I have no doubts about His } \\
\text { existence }\end{array}$} & $\square$ Reference group ( $\mathrm{N}=115$ ) \\
\hline & $51,30 \%$ \\
\hline & $179,03 \%$ \\
\hline \multirow{2}{*}{$\begin{array}{l}\text { I believe in God, although I have experience } \\
\text { passing doubts as to Gods existence }\end{array}$} & \multirow{2}{*}{$\begin{array}{l}20,97 \% \\
37,39 \%\end{array}$} \\
\hline & \\
\hline \multirow{2}{*}{$\begin{array}{l}\text { Sometimes I feel like I believe in God and } \\
\text { sometimes I don't }\end{array}$} & $\square, 22 \%$ \\
\hline & $0 \%$ \\
\hline \multirow{2}{*}{$\begin{array}{l}\text { I do not believe in a personal God, but I do } \\
\text { believe in some kind of Higher Power }\end{array}$} & $6,09 \%$ \\
\hline & $0 \%$ \\
\hline I don't know if there is a God, and I don't & $0 \%$ \\
\hline believe there is a way to find out & $0 \%$ \\
\hline I don't believe in God & $\begin{array}{l}0 \% \\
0 \%\end{array}$ \\
\hline
\end{tabular}

Mann-Whitney test indicates that the difference is statically significant as the level of $p<0.001$

\section{Religious practices of the research participants}

Persons who participate in surveys that use the Scale of Religious Practices evaluate their own religiosity in the aspects of frequency, nature and importance of religious practices (prayer, mass participation, taking Holy Communion, motivation and meaning of religious practices). 30 points is the maximum score, 5 points - the minimum, with the normalized average at 17,5 points (Chaim 1991, 120, 195).

Table 5. Descriptive statistics of the research participants' $(N=207)$ in the Scale of Religious Practices (W. Prężyna/W.Chaim)

\begin{tabular}{|l|c|c|c|c|c|c|c|c|}
\hline RPS & N & Min & Max & M & SD & Skewness & Kurtosis & $\begin{array}{c}\text { Mann-Whitney } \\
\text { test } \\
\text { confidence level }\end{array}$ \\
\cline { 1 - 7 } $\begin{array}{l}\text { Postgraduate } \\
\text { students }\end{array}$ & 62 & 16.00 & 28.00 & 23.23 & 2.21 & -0.34 & 0.71 & 0.001 \\
\cline { 1 - 6 } Reference group & 145 & 6.00 & 25.00 & 16.95 & 4.35 & -0.09 & -0.57 & \\
\hline
\end{tabular}

The average result of the postgraduate students of theology in Scale of Religious Practices $(M=23.2)$ is higher than the normalized average of the scale 
$(\mathrm{M}=17.5)$ and significantly higher $(\mathrm{P}<0.001)$ than the reference group average $(\mathrm{M}=17.0)$. The postgraduate students of theology are also somewhat more homogeneous as a group than the reference group of other adult Catholics, as evidenced by the lower standard deviation $(\mathrm{SD}=2.2$ as compared to $\mathrm{SD}=4.4$ ). Skewness to the left (-0.3) indicates that the majority of the results were higher than the average, which can be explained by the religious profile of the theology programs in which the participants are enrolled. In the reference group, the average score was lower and the skewness was closer to zero $(-0.1)$, which indicated a more symmetrical distribution, meaning that individual scores were both higher and lower than the normalized average. This means that postgraduate students of theology participate more strongly in religious practices and value these practices more than the Catholics from the reference group.

An ecclesiastic community, as noted by Le Bras, realizes itself in practice trough mass participation and communion, rather than in the sacrament of the baptism as stated by theology of sacraments. A person who is baptized, but does not take part in masses or take communion, can be considered to be dead member as a member of the Church (Le Bras 1956, after: Piwowarski, Mariański, Ryczan 1987, 117). However participating in the mass is an important indicator or institutionalized religiosity, and may be a symptom of routine, relatively superficial, mass religiosity. Receiving communion, on the other hand, may be an indicator not just of private, but also of deeper religios-

Graph 4. Frequency of participation in mass among the research participants $(\mathrm{N}=207)$

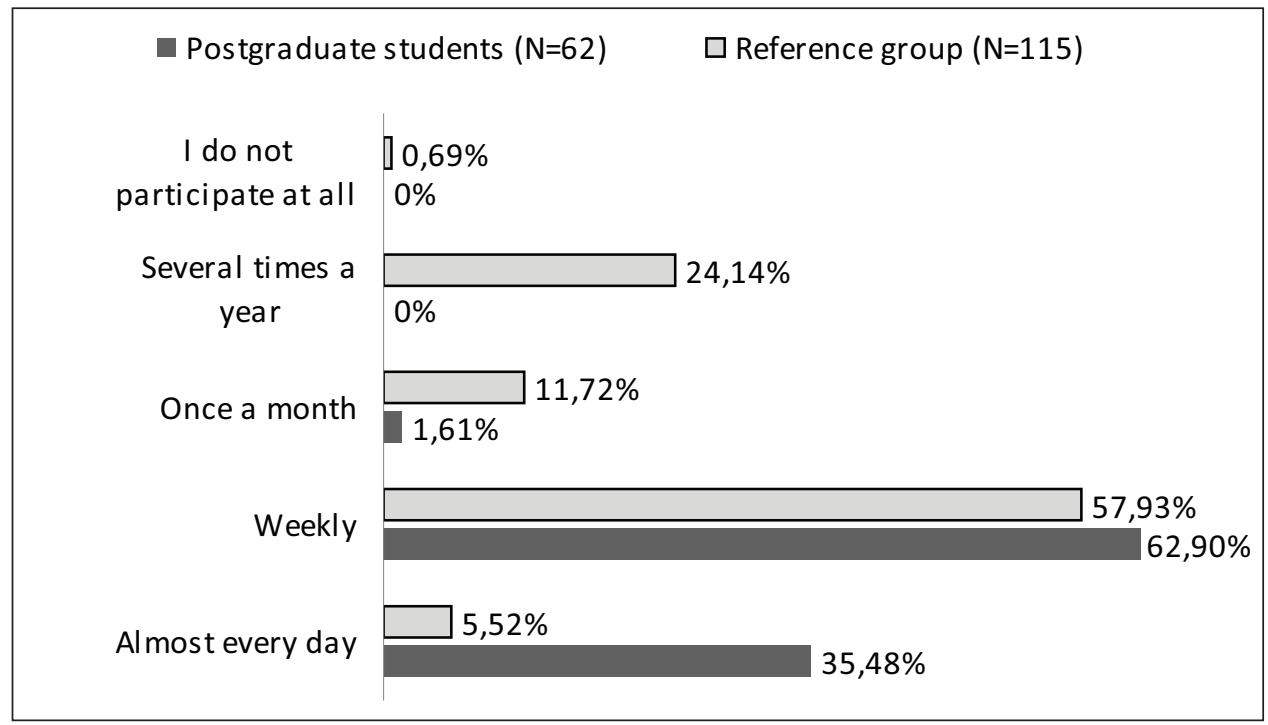

Mann-Whitney test indicates statistic significance of the difference at the level of $p<0.001$ 
ity. Thus, a high percentage of dominicantes does not always correspond to an equal number of communicantes.

According to the participants' declarations almost all (98.4\%) of the postgraduate students of theology and $62.9 \%$ of the adult Catholics from the reference groups take part in mass at least once a week. The results in the reference groups correspond broadly with the results of Statistics Poland national survey on the same subject ${ }^{7}$. Significant differences between the two groups concern mostly daily participation in mass (which is more common among the postgraduate students: $35.5 \%$ as compared to $5.5 \%$ ) and participating only several times a year, which is the declared practice of $24.1 \%$ adult Catholics from the reference group. There is also a smaller difference regarding the percentage of persons who participate in mass once a month: $11.7 \%$ of participants from the reference group and $1.6 \%$ of the postgraduate students.

Graph 5. Frequency of taking Communion among research participants $(\mathrm{N}=207)$

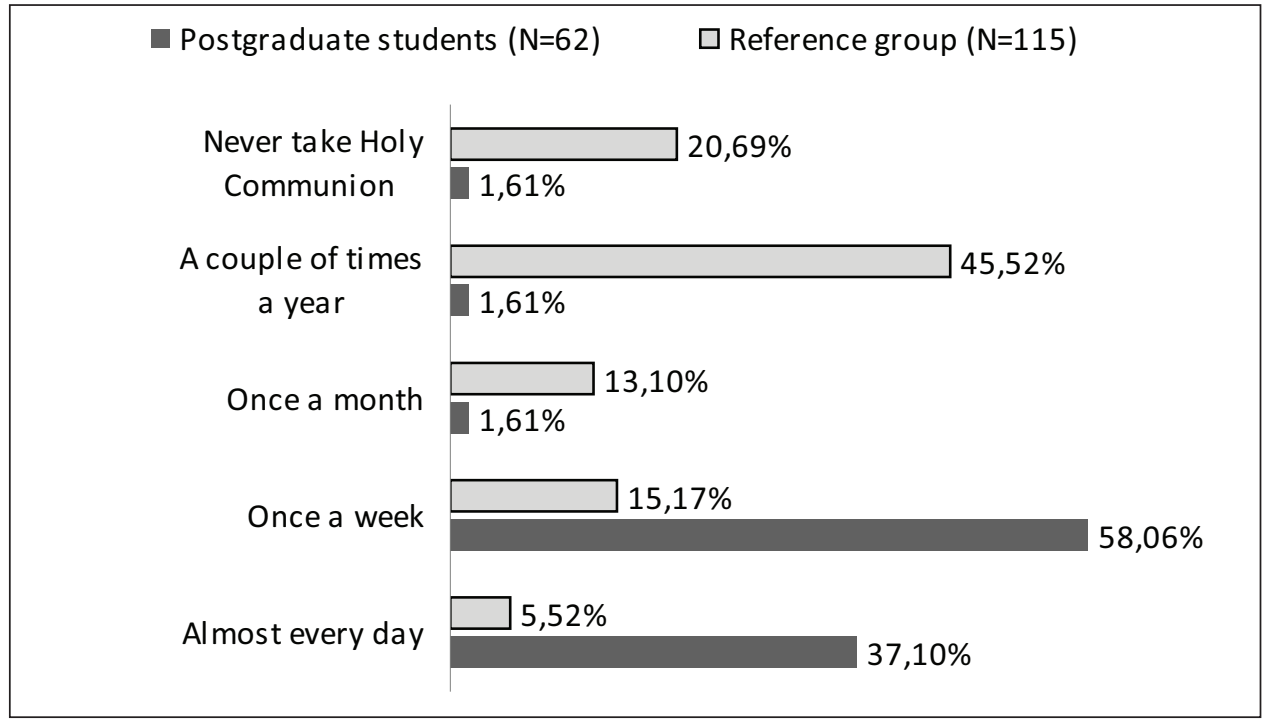

Mann-Whitney test indicates that the difference is statistically significant at the level of $\mathrm{p}<0.001$

Significant $(\mathrm{p}<0.001)$, notable differences between the two groups concern receiving the Holy Communion (Graph 5). Almost all (95.2\%) of postgradu-

${ }^{7}$ According to Statistics Poland survey 2.9-3.3\% of Poles aged between 35 and 54 declare to participate in mass more than once a week, while $50.7-51.2 \%$ attend mass once a week (Statistics Poland. Statistical Office in Łódź 2017, 117). The reference group result may be somewhat higher than that of the general population given that it is a self-selecting group of parents whose children prepare for the First Communion. 
ate students who took part in the research, take Holy Communion every time when they attend mass, which means they do it at least once a week. Conversely, among the adult Catholics from the reference group only $20.7 \%$ receive communion once a week or more frequently. When taking into account the previous conclusion (see: Graph 4) that $57.9 \%$ of the reference group take part in mass every week, one notes that only one in three persons from the reference group receives communion every time they attend the Sunday mass. The others in this group only participate in this practice during religious feasts and holidays (45.5\%) or never take Holy Communion $(20.7 \%)^{8}$.

Individual prayer, which expresses one's personal experience of faith, is another indicator of religiosity. It is a sign of personal contact between an individual and God. As shown in Graph 6, almost all of the postgraduate students of theology declared that pray everyday or almost everyday (98.4\% in total), while just above half (55.8\%) of the adult Catholics from the reference group pray with similar frequency. The other respondents from the reference group pray several times a month $(24.1 \%)$ or less frequently $(20.0 \%)$. The difference between the two groups is statistically significant $(\mathrm{p}<0.001)$.

Graph 6. Frequency of prayer among research participants $(\mathrm{N}=207)$

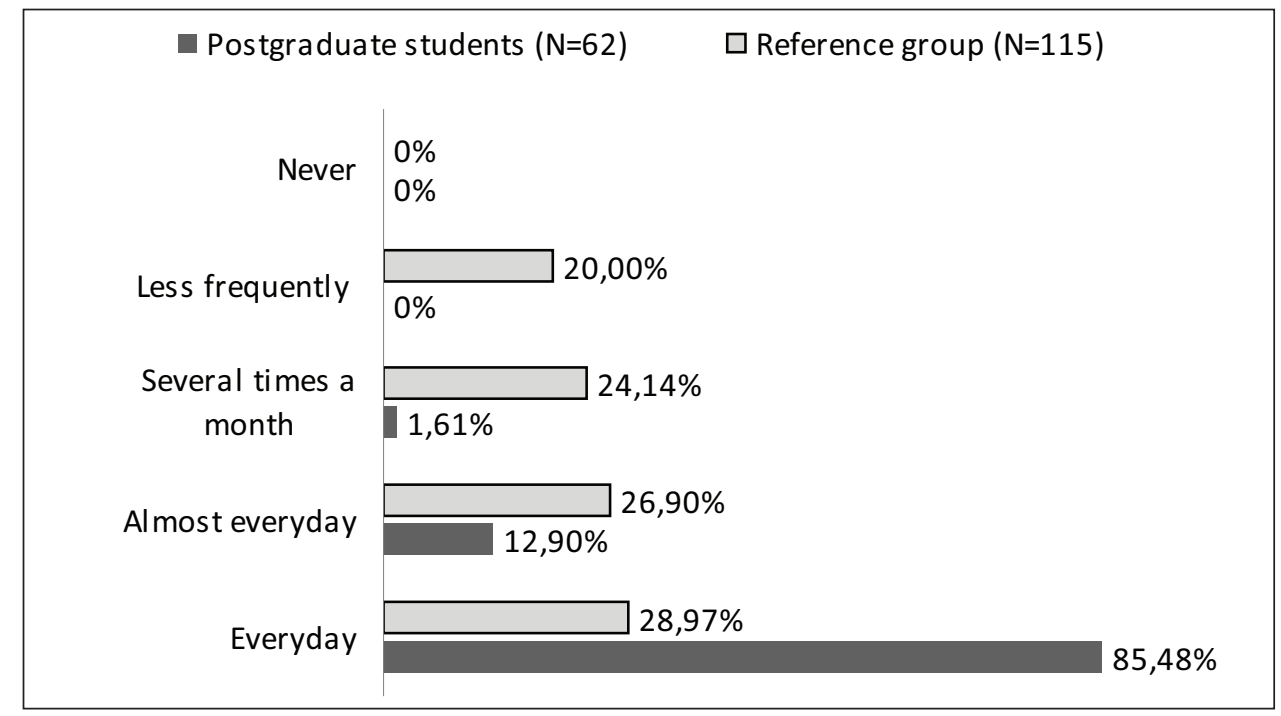

Mann-Whitney test indicates statistic significance of the difference at the level of $p<0.001$

In the opinion of the postgraduate students of theology the relationship between their morality and religion (Graph 7) is mostly strong or very strong

${ }^{8}$ This percentage corresponds with the percentage of persons in „martially irregular situations” (cf. Table 3). 
$(83.9 \%)$, while fewer of them evaluate it as medium (16.1\%). Persons from the reference group are most likely (54.8\%) to describe it as medium, less likely to evaluate it either as strong or very strong, and the least likely to describe it as weak or very weak (13\%). The self-evaluation of relationship between morality and religion differs significantly between the two groups.

Graph 7. Self-evaluation of relationship between morality and religion among the research participants $(\mathrm{N}=177)$

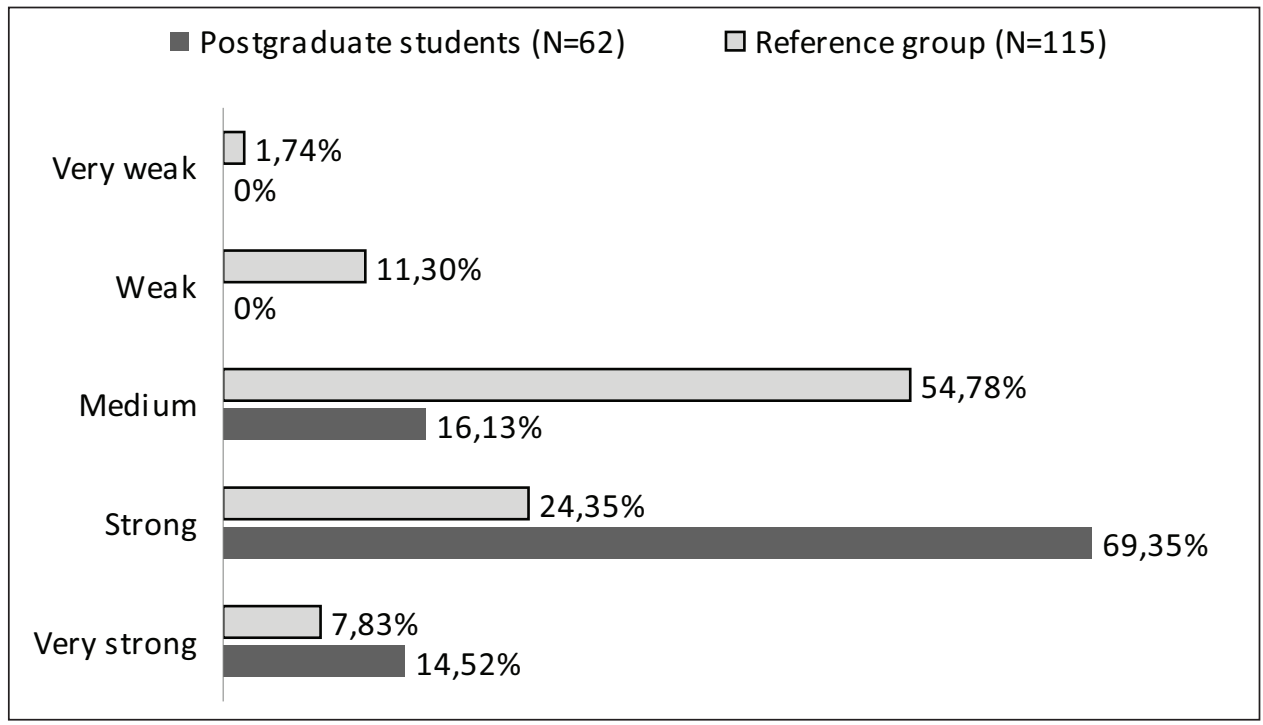

Mann-Whitney test indicates statistic significance of the difference at the level of $p<0.001$

\section{Communal and ecclesiastic aspects of religiosity}

The vast majority ( $85 \%$ ) of postgraduate students of theology evaluated their personal relationship with the Church as strong or very strong (Graph 8). Only $30 \%$ of the adult Catholics from the reference group gave similar self-evaluation. Almost half (45\%) of the participants from the reference group described their relationship with the Church as medium, and nearly a quarter - as weak or very weak. The differences between the groups are statistically significant.

Aside from self-evaluation, the participants' relationship with the Church can also be analyzed based on their involvement in various ministry groups (Table 6). One can note a very significant difference in this type of ecclesiastic engagement between the two groups $(p<0.001)$. Two thirds $(66 \%)$ of the adult Catholics from the reference group have never belonged to any such groups, while the same is true for only one in five $(21 \%)$ of the postgraduate students 
Graph 8. Self-evaluation of participants' relation with the Church $(\mathrm{N}=177)$

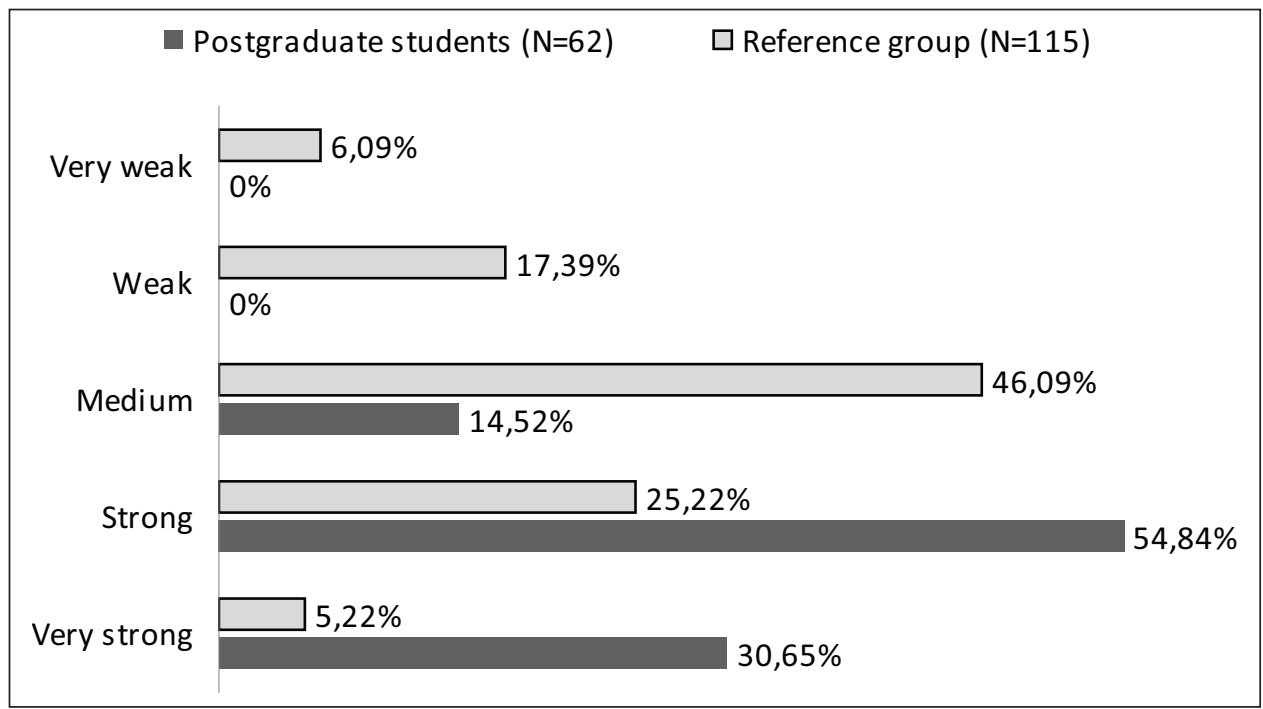

of theology. Conversely, almost half (45\%) of the postgraduate students have been and continue to be stable members of such groups, while this figure is much lower for the reference group (5.5\%).

Table 6. Membership in ministry groups and/or other Church communities $(\mathrm{N}=207)$

\begin{tabular}{|c|c|c|c|c|c|}
\hline & \multicolumn{2}{|c|}{$\begin{array}{c}\text { Postgraduate students } \\
\qquad(\mathrm{N}=62)\end{array}$} & \multicolumn{2}{|c|}{$\begin{array}{l}\text { Reference group } \\
\qquad(\mathrm{N}=145)\end{array}$} & \multirow{2}{*}{$\begin{array}{c}\text { Mann-Whitney } \\
\text { test } \\
\text { confidence level }\end{array}$} \\
\hline & $\mathbf{n}$ & $\%$ & $\mathbf{n}$ & $\%$ & \\
\hline $\begin{array}{l}\text { I have never belonged } \\
\text { to such a group }\end{array}$ & 13 & 20.97 & 96 & 66.21 & \multirow{5}{*}{0.001} \\
\hline $\begin{array}{l}\text { I used to belong to such } \\
\text { a group and I currently } \\
\text { belong to one }\end{array}$ & 28 & 45.16 & 8 & 5.52 & \\
\hline $\begin{array}{l}\text { I used to belong to such } \\
\text { a group but I no longer do }\end{array}$ & 11 & 17.74 & 20 & 13.79 & \\
\hline $\begin{array}{l}\text { I used not to belong } \\
\text { to such a group, but } \\
\text { I currently belong to one }\end{array}$ & 10 & 16.13 & 14 & 9.66 & \\
\hline No data & 0 & 0 & 7 & 4.83 & \\
\hline
\end{tabular}

The postgraduate students of theology most commonly used to belong to the following groups: Bible circles $(21 \%)$, schola, choir or other musical 
group (16\%), youth group or Catholic Youth Organization (13\%), Renewal in Holy Spirit community (11\%) and the Life-Light Movement (11\%). The adult Catholics from the reference group most commonly used to belong to the LifeLight Movement (7\%), choir or other musical group (3\%), Renewal in Holy Spirit community (4\%) or altar servers' group (3\%). Currently, the postgraduate students of theology most commonly belong to such groups and communities as: The Living Rosary Association (15\%), Domus Ecclesiae (13\%), Bible circle $(10 \%)$, pastoral council $(8 \%)$, catechists $(7 \%)$, schola, choir or other musical group (7\%), monastic order (7\%). In the reference group, the most persons are involved in the activities of Domus Ecclesiae (2\%) and The Living Rosary Association (2\%).

Graph 9. The research participants' attendance at communal worship practices and pastoral events $(\mathrm{N}=177)$

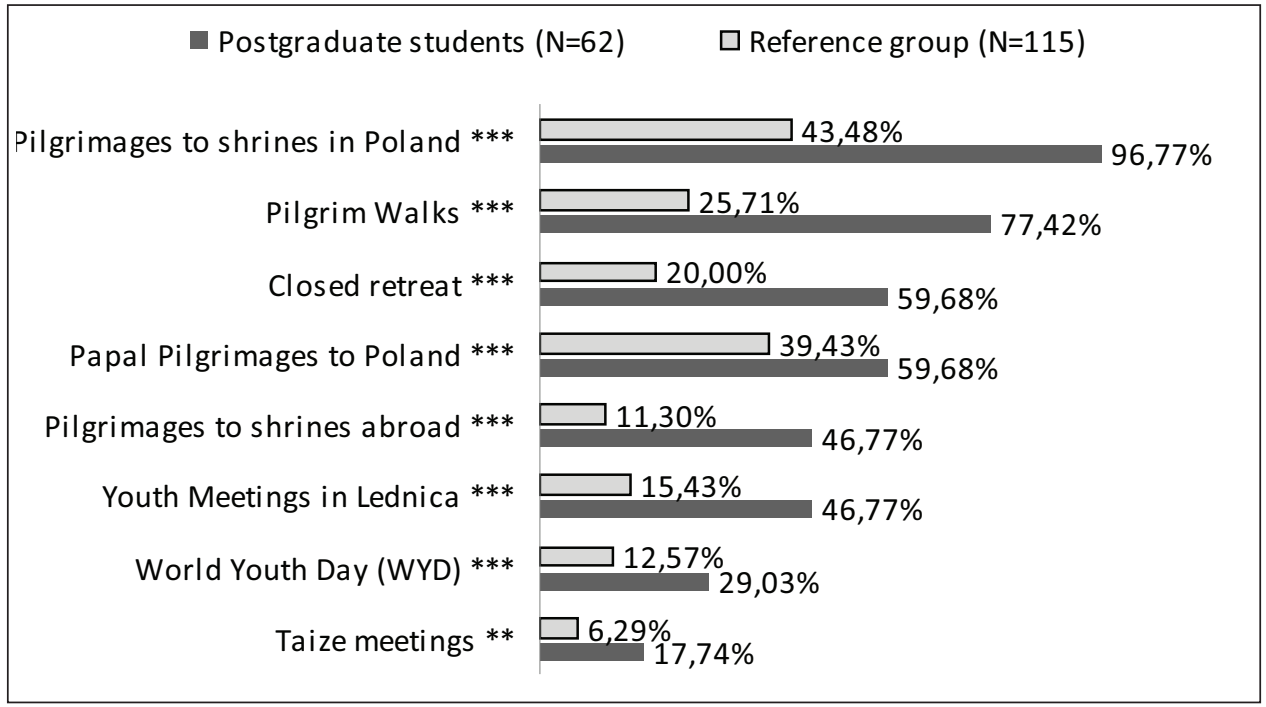

The asterisks mark the statistic significance of the difference according to the Mann-Whitney test, where $* * *$ is $\mathrm{p}<0.001$ and $* *$ is $\mathrm{p}<0.01$

The communal aspect of religiosity and the relationship of the Church can also be analyzed using the data on participation in communal worship practices and other pastoral events that go beyond the obligation to participate in Sunday mass. As shown in Graph 9, the postgraduates students of theology have taken part in such events significantly more often than the adult Catholics from the reference group. They are also more likely to have participated in such worship practices multiple times (in case of pilgrimages to sanctuaries the average for the postgraduate students was $M=10.2$, and in case of spir- 
itual exercises for closed groups $-\mathrm{M}=5.8$; the averages for the reference group were, respectively, $\mathrm{M}=2$ and $\mathrm{M}=0.7$ ).

\section{Religious identity of the research participants}

Table 7 and Graph 10 show the average scores of the participants from both groups in the A. Wieradzka-Pilarczyk's (2015) Scale of Religious Identity (STR). Two characteristics that are particular for both groups are the positive averages in the fields of accepting obligations in the areas that are important for the development of one's own religious identity (PZ) and identification with the accepted obligations and one's own choices (IZ), which means that the participants are internalizing their religious obligations and feel certain that the choices they make/have made are good and correspond with their own needs. Conversely, negative averages in the aspect of wide exploration (EW), in-depth exploration (EG) and ruminative exploration (ER) indicate that the research participants currently do not go trough neither of the following processes: wide exploration, which comprises the search of different options of religious self-identification; in-depth exploration which is the process of searching for information on the choices one has taken; ruminative exploration which is symptomatized by ruminative anxiety and developmental difficulties related to the acceptance of obligations.

Table 7. Descriptive statistics of research participants' STR (A. Wieradzka-Pilarczyk) scores $(\mathrm{N}=177)$

\begin{tabular}{|c|c|c|c|c|c|c|c|c|}
\hline \multicolumn{2}{|l|}{ STR } & $\mathbf{N}$ & $\min$ & $\max$ & $\mathbf{M}$ & SD & Skewness & Kurtosis \\
\hline \multirow{5}{*}{$\begin{array}{l}\text { Postgraduate } \\
\text { students }\end{array}$} & $\mathrm{EW} * * *$ & \multirow[t]{5}{*}{62} & -3.97 & 0.03 & -2.54 & 1.09 & 0.70 & -0.21 \\
\hline & $\mathrm{EG} * * *$ & & -3.81 & 1.53 & -1.25 & 1,22 & 0.30 & -0.32 \\
\hline & $\mathrm{ER} * * *$ & & -3.97 & 0.83 & -2.11 & 0.88 & 0.54 & 1.08 \\
\hline & $\mathrm{PZ}$ & & -1.47 & 2.03 & 1.32 & 0.64 & -1.82 & 5.46 \\
\hline & $\mathrm{IZ}$ & & -1.89 & 2.03 & 1.23 & 0.72 & -1.57 & 4.33 \\
\hline \multirow{5}{*}{$\begin{array}{l}\text { Reference } \\
\text { group }\end{array}$} & $\mathrm{EW} * * *$ & \multirow[t]{5}{*}{115} & -3.00 & 3.00 & -1.22 & 1.34 & 0.84 & 0.44 \\
\hline & $\mathrm{EG} * * *$ & & -2.50 & 2.17 & -0.12 & 0.93 & -0.25 & 0.00 \\
\hline & $\mathrm{ER} * * *$ & & -3.00 & 2.00 & -0.61 & 0.95 & 0.20 & -0.15 \\
\hline & $\mathrm{PZ}$ & & -1.67 & 3.00 & 1.54 & 0.95 & -0.69 & 0.92 \\
\hline & IZ & & -1.67 & 3.00 & 1.13 & 1.02 & -0.24 & -0.36 \\
\hline
\end{tabular}

*** means that the statistic significance of the difference is at $\mathrm{p}<0.001$. Due to the normal distribution of results, independent sample t-test was used for EG and ER scales. Mann-Whitney test was used for the other scales 
In all three dimensions of exploration there were statistically significant differences between the two groups ( $<<0.001)$, but they are only quantitative, as the averages for both groups are negative. It seems that postgraduate students of theology are more stable in that aspect, given that their averages are further from zero the the averages of the reference group. It appears, then, that for them the process of seeking their identities (wide exploration EW and in-depth exploration EG) is over and they have reached a satisfactory level of religious self-identification or that they have never undergone this process in the first place. It is possible that they have accepted their religious identity from their environment and have always functioned without considering other alternatives. The respondents from the reference group, while they do not show exploration either, appear to be less stable (with the average scores being closer to zero), especially when it comes to in-depth exploration (EG), where the average score is negative, but very close to zero $(\mathrm{M}=-0.1)$. An average this close to zero indicates that relatively many of the respondents $(n=51 ; 44.3 \%)$ have positive scores, meaning that they are still analyzing and evaluating their choices and obligations and they are still gathering relevant information. Among the postgraduate students of theology, there are much fewer persons $(n=11 ; 17.8 \%)$ who are still open to this kind of deepening analysis concerning their own choices and obligations (positive EG). The greater stability of the postgraduate students' religious identity can be also attested by their average score in the dimension of ER, which shows a significantly lower level of developmental anxiety related to the formation of their religious identity than in the case of adult Catholics from the reference group ( $\mathrm{M}=-2.1$ as compared to $\mathrm{M}=-0.6)$.

The scores of participants from both groups correspond with the STR results of people in early adulthood (26-40) collected by Anna Wieradzka-Pilarczyk $(2015,172)$. This is in line with the religious identity theory which states that the period of early adulthood is a time of intensifying of processes of obligation based on earlier developmental stages. Adults no longer experience serious dilemmas or anxieties related to the choice of a given worldview and the corresponding walk of life or religious status. The activity of adults is focused on following the direction they have already chosen.

After the analysis of average STR scores, the research participants were then classified according to their identity status, using k-means clustering. The most numerous group of postgraduate students $n=48(77.4 \%)$ had the status of external religious identity (Graph 11). It is followed by a group of eleven $(17.8 \%)$ of postgraduate students whose scores indicate the status of internalized religious identity. There are only three $(4.8 \%)$ persons with the status of indifferent religious identity. None of the postgraduate students has the status of exploratory or ruminative religious identity. The percentage distribution of identity statuses was somewhat different in the group with a larger proportion 
Graph 10. The average scores of the research participants $(\mathrm{N}=177)$ concerning different dimensions of their religious identity as measured by STR (A.Wieradzka-Pilarczyk)

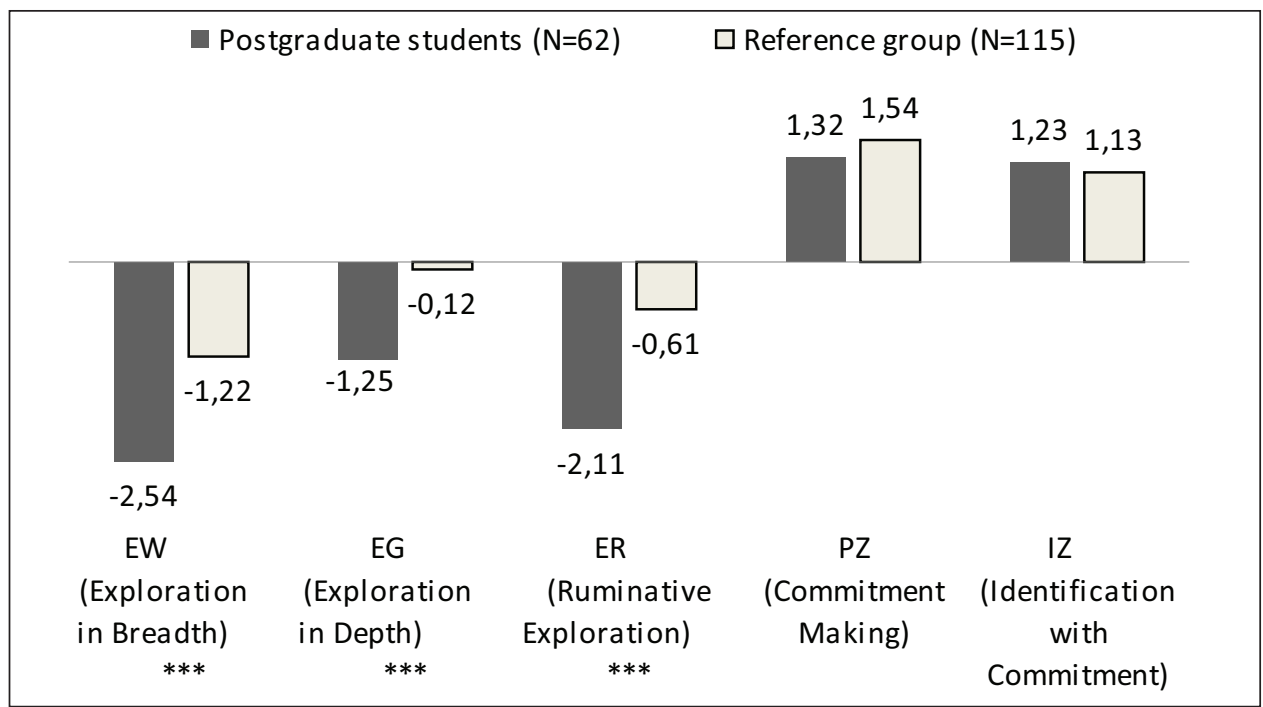

The asterisks mark the statistic significance of the differences: $* * *-p<0.001$. Due to the normal distribution of results, independent sample t-test was used for EG and ER scales. Mann-Whitney test was used for the other scales

$(48.7 \%)$ of internalized religious identity, and a smaller proportion of external religious identity. The percentage breakdown in the reference group (Table 8) is closer to the distribution observed by A. Wieradzka-Pilarczyk $(2015,178)$ for persons in early adulthood. The differences can be explained by the possibility that only those who had the status of external religious identity decided to enroll in a postgraduate theology program. In case of these students, the need to seek new alternatives in the field of religiosity has been satisfied or extinguished yet, at the same time, the religious realm has significant influence on the solutions they adopt in regards to their lifestyle, values and community structures.

Table 8. Percentage distribution of identity statuses among the research participants $(\mathrm{N}=177)$ and persons in early adulthood $(\mathrm{N}=101)$ A. Wieradzka-Pilarczyk

\begin{tabular}{|l|c|c|c|c|c|}
\hline & $\begin{array}{c}\text { Exploratory } \\
\text { religious } \\
\text { identity }\end{array}$ & $\begin{array}{c}\text { External } \\
\text { religious } \\
\text { identity }\end{array}$ & $\begin{array}{c}\text { Indifferent } \\
\text { religious } \\
\text { identity }\end{array}$ & $\begin{array}{c}\text { Ruminative } \\
\text { religious } \\
\text { identity }\end{array}$ & $\begin{array}{c}\text { Internalized } \\
\text { religious } \\
\text { identity }\end{array}$ \\
\hline $\begin{array}{l}\text { Postgraduate } \\
\text { students (N=62) }\end{array}$ & $0 \%$ & $77.4 \%$ & $4.8 \%$ & $0 \%$ & $17.8 \%$ \\
\hline $\begin{array}{l}\text { Reference group } \\
(\mathrm{N}=115)\end{array}$ & $0 \%$ & $42.6 \%$ & $8.7 \%$ & $0 \%$ & $48.7 \%$ \\
\hline Adults ( $\mathrm{N}=101)$ & $2.0 \%$ & $49.5 \%$ & $9.9 \%$ & $2.0 \%$ & $36.6 \%$ \\
\hline
\end{tabular}


Graph 11. Clusters of various identity statuses among the postgraduate students of theology ( $\mathrm{N}=62$ ) according to their STR (A. Wieradzka-Pilarczyk) scores

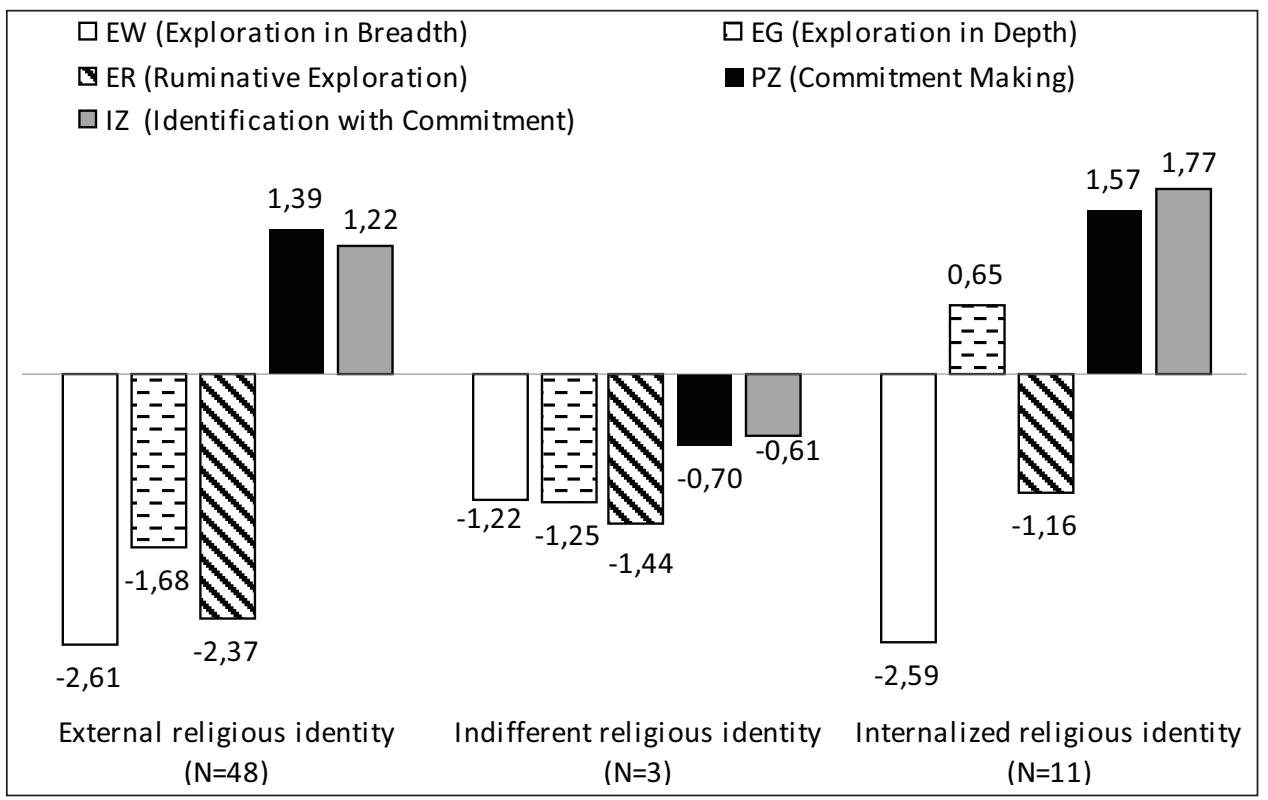

\section{Personal religiosity of the research participants}

Given the personal character of Christianity's object of worship, the tripersonal God, the optimum of personal development and mature religious relationship is constituted by creating a personal bond with the Lord (Prężyna 1990, 270). The individual, as a subject of such a bond, engages his or hers entire „I" into a direct meeting with God's „You”. He or she feels free and creative in his or hers action, remains conscious of the purpose and of his or hers own dignity. This personal relationship with God is a central, stable and durable value, which is also an indicator of religious maturity (Jaworski 1989, 159). Conversely, lack of a personal relationship with God results in impersonal religiosity, in which God is treated as an instrument for satisfying the individual's needs. Religion is subordinate to other life goals. People who experience this kind of religiosity feel no responsibility for the state of their relationship with God, which in turn frees them for the obligation to deepen or strengthen this bond. Religion and God become peripheral values, isolated from other aspects of life, which is an indicator of religious immaturity. A personal relationship is allocentric, while an impersonal relationship is egocentric. 
Table 9. Descriptive statistics of the search participants' scores in the Scale of Personal Religiosity (R. Jaworski) ( $\mathrm{N}=112$ )

\begin{tabular}{|c|c|c|c|c|c|c|c|c|}
\hline \multicolumn{2}{|l|}{ SRP } & $\mathbf{N}$ & Min & Max & M & SD & Skewness & Kurtosis \\
\hline \multirow{5}{*}{$\begin{array}{l}\text { Postgraduate } \\
\text { students }\end{array}$} & SRP total & \multirow{5}{*}{62} & 131 & 203 & 172.47 & 18.60 & -0.61 & -0.61 \\
\hline & Faith (WR) & & 26.00 & 56.00 & 44.37 & 7.03 & -0.88 & -0.19 \\
\hline & Morality (MR) & & 33.00 & 49.00 & 41.47 & 3.60 & -0.12 & -0.57 \\
\hline & Religious practices (PR) & & 35.00 & 63.00 & 50.95 & 7.40 & -0.46 & -0.76 \\
\hline & Self-identification (SR) & & 24.00 & 47.00 & 35.63 & 5.41 & -0.61 & -0.54 \\
\hline \multirow{5}{*}{$\begin{array}{l}\text { Reference } \\
\text { group }\end{array}$} & SRP total & \multirow{5}{*}{60} & 109 & 200 & 151.72 & 21.35 & 0.018 & -0.31 \\
\hline & Faith (WR) & & 30.00 & 50.00 & 41.03 & 5.41 & -0.11 & -0.82 \\
\hline & Morality (MR) & & 22.00 & 47.00 & 35.50 & 5.60 & -0.04 & -0.07 \\
\hline & Religious practices (PR) & & 27.00 & 63.00 & 43.73 & 8.23 & 0.06 & -0.08 \\
\hline & Self-identification (SR) & & 22.00 & 42.00 & 31.45 & 4.75 & -0.17 & -0.45 \\
\hline
\end{tabular}

The differences in all scales and subscales of SRP are statistically significant at the level of $p<0.001$. Independent samples t-test was used for the morality scale (MR) due to the normal distribution of results. Mann-Whitney test was used for the other scales.

The average score of the postgraduate students of theology $(M=172.5)$ in the Scale of Personal Religiosity (SRP) is significantly higher than the normalized average $(M=120.0)$ and higher than the reference group average $(\mathrm{M}=151.7)$. Moreover, the postgraduate students of theology appear to be a somewhat more homogeneous group than the reference group, as evidenced by the lower standard deviation value ( $\mathrm{SD}=18.6$ as compared to $\mathrm{SD}=21.4$ ). Skewness to the left $(-0.61)$ and the fact that all scores were higher than $130 \mathrm{p}$. can be explained by the religious profile of the programs and faculty they attend. In the reference group, skewness was close to zero (0.02), which indicates a symmetrical distribution - there were scores both lower and higher than the normalized average. Thus, all of the examined postgraduate students of theology are characterized by religiosity that is typically persona, allocentric and engaged, which means that they have achieved a mature religious relationship.

\section{Conclusions}

The results confirm that it is reasonable to expect postgraduate students of theology to have a higher level of religiosity. The independent variable of deciding to enroll in a postgraduate theology program is significantly connected 
with a higher intensity of selected psychological variables than in the cares of other Catholics with higher education. Thus, in reference to particular variables one can observe the following:

- Postgraduate students of theology are much less likely to have doubts concerning the existence of God they believe in. They are several times more likely than other Catholics to accept the image of God as the „beloved Dad", which shows filial devotion. There are also twice as likely to describe God as a „friend”, which is sign of a close, personal bond with God, which is based on the covenant.

- Postgraduate students of theology are significantly more involved in sacramental and religious life than other Catholics. Their religious practices are more intensive and they also attribute more value to practicing their religion than most Catholics; almost all (95\%) of the students who participated in the research receive the Holy Communion every time they attend mass, which they to at least once a week. Thus they are living, active members of the Church.

- The postgraduate students of theology sense a stronger bond with the Church and show a greater involvement in the life of their Church community than other Catholics. They have been and continue to be animators of Christian life, participating in many grassroots movements, religious groups and communities. The theology programs they attend naturally prepare them for even more fruitful formative work.

- The status of external religious identity dominates among postgraduate students of theology (characterizing $77 \%$ of the participants), which confirms the theory of religious identity according to which adulthood is the time of intensifying the processes of internalization of obligations. The percentage of persons with the status of internalized religious identity is relatively lower among the postgraduate students of theology than in the general population, which may be caused by the fact that their past religious development and ecclesiastic engagement either did not require them to verify their existing religious self-identification or have satisfied their need to seek other options and their interest in the religious realm. Their developmental processes have more depth than in case of other Catholics. They no longer experience anxiety in regards to the choice of their worldview, yet at the same time the religious aspect of their lives has a strong influence on their lifestyle, values and on the community and familial structures they co-create.

- In the dimension of personal religiosity it is evident that the postgraduate students of theology are characterized by typically personal, allocentric, creative, engaged religiosity, which indicates that their religiosity 
is significantly more mature than the religiosity of Catholics from the reference group.

More detailed data could be obtained by analyzing the religiosity of postgraduate students of theology against personality-related variables.

Theology is one of the fundamental elements of the Church's life. It is an important and indispensable vocation. As an ecclesiastic vocation it should be based upon living faith, a mature, personal bond with Jesus Christ and on zeal in reaching the truth that was revealed in Him. It is a theologian's role to accept this truth as his or hers personal truth trough living faith and to comprehensively communicate it to his or hers contemporaries. The fundamental task of theologians is to allow the future generations to understand the deep, human value of faith, which permeates one's life and which shall be made visible by the Christian community (Królikowski 2018, 37). The results of the above analyses are show that the first students who decided to enroll in the new postgraduate theology programs, fulfill all the requirements of the Holy Church and of the University (Marciniak 2016a; Marciniak 2016b) in regards to spiritual competences related to spiritual development, the development of faith. When compared to the general populace of Catholics, there are the elite of the disciples, which shall be ,the salt of the earth” (Misiaszek 2013, 105).

\author{
WYBRANE WSKAŹNIKI RELIGIJNOŚCI \\ SŁUCHACZY STUDIÓW PODYPLOMOWYCH TEOLOGII W POZNANIU
}

\title{
Streszczenie
}

Prezentowany artykuł jest raportem z empirycznych studiów dotyczących religijności słuchaczy studiów podyplomowych teologii, którzy przygotowują się do nauczania religii w szkołach i przedszkolach. Sformułowano następujący problem badawczy: czy słuchacze studiów podyplomowych teologii są osobami posiadającym kompetencje duchowe w aspekcie ich rozwoju religijnego i rozwoju wiary, tak aby mogli w przyszłości umiejętnie wspierać duchowo swoich uczniów? Czy są religijni i czy ich religijność posiada cechy dojrzałości? W celu weryfikacji hipotezy badawczej wykorzystano następujące narzędzia diagnostyczne: ankietę do badania wymiarów religijności, Skalę Praktyk Religijnych (Chaim 1991), Skalę Tożsamości Religijnej A. Wieradzkiej-Pilarczyk (2015), Skalę Religijności Personalnej R. Jaworskiego (1989). Badania przeprowadzono w latach 2017-2019 wśród słuchaczy (N=62) Studiów Podyplomowych Teologiczno-Katechetycznych oraz Studiów Podyplomowych Katechezy Przedszkolnej na WT UAM w Poznaniu. Grupę porównawczą stanowili 
posiadający wyższe wykształcenie rodzice dzieci pierwszokomunijnych $(\mathrm{N}=145)$. Wszyscy badani byli wyznania rzymskokatolickiego. Uzyskane wyniki potwierdzają zasadność oczekiwania, że słuchaczy studiów podyplomowych teologii powinien charakteryzować wyższy poziom religijności. Zmienna niezależna, jaką jest podjęcie studiów podyplomowych teologii, łączy się w sposób istotny z wyższym niż u innych dorosłych katolików poziomem intensywności wyróżnionych zmiennych psychologicznych, takich jak: autodeklaracja wiary, obraz Boga, praktyki sakramentalne i religijne, zaangażowanie w życie wspólnoty kościelnej, tożsamość religijna oraz religijność personalna.

Słowa kluczowe: studia podyplomowe teologii, obraz Boga, praktyki religijne, zaangażowanie eklezjalne, tożsamość religijna, religijność personalna

Keywords: postgraduate theology studies, the image of God, religious practices, ecclesial commitment, religious identity, personal religiosity.

\section{BIBLIOGRAPHY}

Chaim, Władysław. 1991. Psychologiczna analiza religijności niespójnej. Lublin: RW KUL.

Chlewiński, Zdzisław. 1982a. „Rola religii w funkcjonowaniu osobowości”. In: Psychologia religii, edited by Zdzisław Chlewiński, 61-76. Lublin: TN KUL.

Chlewiński, Zdzisław. 1982b. „Wprowadzenie do psychologii religii”. In: Psychologia religii, edited by Zdzisław Chlewiński, 11-60. Lublin: TN KUL.

Chlewiński, Zdzisław. 1991. Dojrzałość: osobowość, sumienie, religijność. Poznań: W drodze.

Głaz, Stanisław. 2003. „Wpływ zmiennych egzystencjonalnych na skutki przeżycia religijnego”. Czasopismo Psychologiczne. Psychological Journal, 9(1): 119-132.

Głaz, Stanisław. 2004. „Wyznaczniki przeżycia religijnego u młodzieży akademickiej”. Studia Psychologica, 5: 81-102.

Główny Urząd Statystyczny. Urząd Statystyczny w Łodzi. 2017. Jakość życia w Polsce w 2015 roku. Wyniki badania spójności spotecznej, Warszawa. Retrieved: 11.01.2020. https://www. google.pl/url? sa $=\mathrm{t} \& \mathrm{rct}=\mathrm{j} \& \mathrm{q}=\&$ esrc $=$ s\& $\&$ source $=$ web $\& \mathrm{~cd}=2 \& \mathrm{cad}=\mathrm{rja} \&$ uact $=8 \& \mathrm{ved}=2 \mathrm{ahUKE}$ wiI9P2kwPzmAhVkl4sKHX46CIgQFjABegQIAxAC\&url=https\%3A\%2F\%2Fstat.gov.pl\%$2 \mathrm{Fdownload} \% 2 \mathrm{Fgfx} \% 2 \mathrm{Fportalinformacyjny} \% 2 \mathrm{Fpl} \% 2 \mathrm{Fdefaultaktualnosci} \% 2 \mathrm{~F} 5486 \% 2 \mathrm{~F} 4 \% 2 \mathrm{~F}$ 2\%2F1\%2Fjakosc_zycia_w_polsce_w_2015_roku.pdf\&usg=AOvVaw3NgMi6zMsCHemszU$7 \mathrm{zjBZp}$.

Golan, Zdzisław. 2006. „Pojęcie religijności”. In: Podstawowe zagadnienia psychologii religii, edited by Stanisław Głaz, 71-79. Kraków: Wydawnictwo WAM.

Gross, Neil and Solon Simmons. 2009. „The religiosity of American college and university professors". Sociology of Religion. 70(2): 101-129.

Hay, David. 1979. "Religious experience amongst a group of post-graduate students. A qualitative study". Journal for Scientific Study of Religion, 18: 164-184.

Jaworski, Romuald. 1989. Psychologiczne korelaty religijności personalnej. Lublin: RW KUL.

Jaworski, Romuald. 1998. „Psychologiczne badania religijności personalnej”. Zeszyty Naukowe KUL, 3-4: 77-88.

KEP. 2016. Uchwała Konferencji Episkopatu Polski z dnia 7 czerwca 2016 roku w sprawie minimalnych wymogów w kształceniu nauczycieli religii. Retrieved: 11.01.2020. https://www. 
katecheta.pl/Aktualnosci/Uchwala-KEP-w-sprawie-minimalnych-wymogow-w-ksztalceniunauczycieli-religii.

Kowalik, Krzysztof. 2003. Funkcja doświadczenia w teologii. Próba oceny teologiczno-metodologicznej dyskusji we współczesnej literaturze niemieckojęzycznej. Lublin: Wydawnictwo KUL.

Król, Józef. 2002. Psychologiczne aspekty badania fenomenu religii. Podstawy teoretycznometodologiczne. Opole: Uniwersytet Opolski. Katedra Psychologii Religii.

Królikowska, Anna. 2009. „Kierunek studiów a religijność i stosunek do religii”. Zeszyty Naukowe Uniwersytetu Szczecińskiego, Studia Sociologica, 19: 59-81.

Królikowski, Janusz. 2016. Nauka, mądrość i powołanie. O naturze i misji teologii. Kraków: WN Uniwersytet Papieski Jana Pawła II w Krakowie. DOI: 10.15633/9788374385145.

Królikowski, Janusz. 2017. „Kontemplacja i racjonalność. Sakralny wymiar teologii”. Wrocławski Przegląd Teologiczny, 25/1: 19-34.

Królikowski, Janusz. 2018. „Teologia jako dziedzina nauki i zadanie dydaktyczne”. Teologia w Polsce, 12.1: 27-39.

Kwas, Angelika. 1982. „Bóg ojcem w Nowym Testamencie”. Ruch Biblijny i Liturgiczny, 35.3: 186$-193$.

Le Bras, Gabriel. 1956. « Études de sociologie religieuse », t. II, De la morphologie a la typologie. Paris: Presses Universitaires de France.

Libiszowska-Żółtkowska, Maria. 1991. Postawy inteligencji wobec religii. Studium socjologiczne. Warszawa: Instytut Filozofii i Socjologii PAN.

Łabuda, Piotr. 2011. „Paweł jako ojciec i Bóg jako «Abba, Ojciec»”. Verbum Vitae 20: 171-190.

Marciniak, Bronisław. 2016a. Zarządzenie Nr 541/2015/2016 Rektora Uniwersytetu im. Adama Mickiewicza w Poznaniu z dnia 14 lipca 2016 r. w sprawie utworzenia Studiów Podyplomowych Teologiczno-Katechetycznych, §1; §3. Retrieved: 11.01.2020. http://teologia.amu.edu. pl/_data/assets/pdf_file/0003/305787/Nr-541_2015_2016-SP-Teologiczno-Katechetyczne.pdf.

Marciniak, Bronisław. 2016b. Zarządzenie nr 550/2015/2016 Rektora Uniwersytetu im. Adama Mickiewicza w Poznaniu z dnia 10 sierpnia 2016 r. w sprawie utworzenia Studiów Podyplomowych Katechezy Przedszkolnej, §1; §3. Retrieved: 11.01.2020. http://teologia.amu.edu.pl/_ data/assets/pdf_file/0004/305788/Nr-550_2015_2016-SP-Katechezy-Przedszkolnej.pdf.

Misiaszek, Kazimierz. 2013. „«Być solą ziemi» jako zadanie katechetyczne”. Teologia pastoralna. Rocznik Teologii Katolickiej, 12: 97-106. DOI: 10.15290/rtk.2013.12.2.06.

Miś, Lucjan: Warmiński, Andrzej. 2000. „Między słabością a siłą. Postawy religijne studentów krakowskiej WSP”. In: Postawy wobec religii. Psychologiczne uwarunkowania i konsekwencje, edited by Tadeusz Doktór and Kazimierz Franczak, 99-108. Warszawa: Salezjański Instytut Wychowania Chrześcijańskiego.

Moskałyk, Jarosław. 2012. „Na drodze poznania wiary”. Teologia w Polsce, 6.2: 41-51.

Nowak, Antoni Jozafat. 1985. „Człowiek - istota religijna. Aspekt psychologiczny”. Śląskie Studia Historyczno-Teologiczne, 18: 203-208.

Piwowarski, Władysław, Janusz Mariański and Kazimierz Ryczan. 1987. Biuletyn socjologii religii. Collectanea Theologica, 57/4: 113-135.

Poniży, Bogdan. 2003. „Sapiencjalne przejście od «przymierza» do «przyjaźni z Bogiem»”. Verbum Vitae, 4: 99-118.

Porozumienie pomiędzy Konferencją Episkopatu Polski oraz Ministrem Edukacji Narodowej z dnia 31 maja 2016 r. w sprawie kwalifikacji wymaganych od nauczycieli religii. 2016. Retrieved: 11.01.2020. https://men.gov.pl/wp-content/uploads/2016/05/60531113700-1.pdf.

Prężyna, Władysław. 1990. „Symptomy dojrzałej religijności”. In: Kościól w służbie człowieka, edited by Władysław Turek and Janusz Mariański, 269-278. Olsztyn: Warmińskie Wydawnictwo Diecezjalne.

Scheitle, Christopher P. 2011. „US college students' perception of religion and science: Conflict, collaboration, or independence? A research note." Journal for the Scientific Study of Religion, 50(1): 175-186. DOI: 10.1111/j.1468-5906.2010.01558.x. 
Scheitle, Christopher P. and Elaine Howard Ecklund. 2018. "Perceptions of religious discrimination among US scientists." Journal for the Scientific Study of Religion, 57(1): 139-155. DOI: $10.1111 /$ jssr. 12503 .

Sobór Watykański II. 2002. "Konstytucja dogmatyczna o Kościele «Lumen gentium»”. In: Sobór Watykański II: Konstytucje, dekrety, deklaracje, 104-166. Poznań: Pallottinum Wydawnictwo Stowarzyszenia Apostolstwa Katolickiego.

Soiński, Borys Jacek. 2006. Doświadczenia religijne a postawy studentów w obliczu śmierci Jana Pawła II. Poznań: UAM WT.

Stark, Rodney and Roger Finke. 2000. Acts of Faith: Explaining the Human Side of Religion, Berkeley: University of California Press.

Strzelczyk, Grzegorz. 2007. „Doświadczenie wiary a teologia. Próba wstępnej systematyzacji problematyki". Teologia w Polsce, 1, 1: 37-49.

Szymik, Jerzy. 2013. „Teologia”. II. „Natura”. In: Encyklopedia katolicka. Tom XIX, edited by S. Wilk et all, k. 657-659. Lublin: TN KUL.

Walesa, Czesław. 1982. „Psychologiczna analiza rozwoju religijności człowieka ze szczególnym uwzględnieniem pierwszych okresów jego ontogenezy". In: Psychologia religii, edited by Zdzisław Chlewiński, 143-190. Lublin: TN KUL.

Wieradzka-Pilarczyk, Anna. 2015. Tożsamość religijna młodych Polaków. Poznań: UAM WT.

Wulff, David M. 1999. Psychologia religii. Klasyczna i wspólczesna. Warszawa: WSiP.

BoRYS JACEK SoIŃSKI OFM - prof. UAM doktor habilitowany nauk teologicznych, dr nauk humanistycznych w zakresie psychologii. Ukończył studia psychologiczne na KUL-u, teologiczne na PAT oraz licencjackie z teologii duchowości (KUL). Profesor nadzwyczajny w Zakładzie Filozofii i Dialogu na Wydziale Teologicznym UAM. Przewodniczący Stowarzyszenia Psychologii Pastoralnej. Należy do Stowarzyszenia Psychologów Chrześcijańskich. Z Zakonu Braci Mniejszych (OFM). 